\title{
Factors affecting the cooking quality of stored carioca beans (Phaseolus vulgaris)
}

\author{
Juliana Aparecida Correia Bento ${ }^{1}$, Karen Carvalho Ferreira ${ }^{1}$, Priscila Zaczuk Bassinello ${ }^{2 *}$, B. Dave Oomah ${ }^{3+}$ \\ ${ }^{1}$ School of Agronomy, Federal University of Goiás-UFG, Goiânia, Brazil; ${ }^{2}$ Embrapa Rice and Beans, Santo Antônio de \\ Goiás, Brazil; ${ }^{3}$ Summerland Research and Development Centre, Agriculture and Agri-Food Canada, Summerland, BC, \\ Canada
}

${ }^{+}$Retired.

*Corresponding Author: Priscila Zaczuk Bassinello, Embrapa Rice and Beans, PO Box 179, Santo Antônio de Goiás, Goiás, 75375-000, Brazil. Email: priscila.bassinello@embrapa.br

Received: 8 March 2021; Accepted: 27 August 2021; Published: 11 November 2021

(C) 2021 Codon Publications

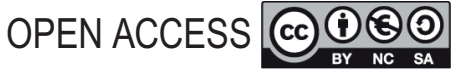

REVIEW

\begin{abstract}
The culinary quality of carioca beans is related to their market value and consumer acceptability. The depreciation of the cooking/technological quality of the product occurs mainly because of the integument browning and the longer cooking time of the grains, which are influenced by the storage time and conditions. The loss of culinary quality reduces the market value of carioca beans because consumers reject darkened grains that are attributed to a longer cooking time. As a result, cooking time (resistance to cooking), the color of the integument, and the texture of the cooked beans are determinant factors in the acceptance of carioca bean cultivars. The browning of the grain integument and the cooking time mainly depends on the environmental conditions, storage time, the tegument of each genotype, and the chemical and physical properties of the cotyledons. Therefore, this review aims to survey the scientific literature on the extrinsic and intrinsic factors that affect the culinary quality of carioca beans.
\end{abstract}

Keywords: browning; cooking time; polyphenolic compounds; quality loss; storage

\section{Introduction}

Beans are cultivated during the whole agricultural year, in distinct ecosystems, principally in developing countries, which are responsible for $86.7 \%$ of world consumption. In 2019, five countries (Myanmar, India, Brazil, China, and the United Republic of Tanzania) accounted for $59 \%$ of the world's dry bean production ( 30.2 million tons; Food and Agriculture Organization of the United Nations, 2019). Beans are rich in essential nutrients like (i) proteins with high lysine content (essential amino acid); (ii) high complex carbohydrate content as oligosaccharides, and dietary fibers with their recognized hypocholesterolemic and hypoglycemic effects; and (iii) complex vitamins and minerals (calcium [Ca], iron $[\mathrm{Fe}]$, copper $[\mathrm{Cu}]$, zinc $[\mathrm{Zn}]$, phosphorus $[\mathrm{P}]$, potassium $[\mathrm{K}]$, and magnesium $[\mathrm{Mg}]$ ); bioactive antioxidant compounds including saponins, polyphenols, and anthocyanins (Ganesan and Xu, 2017; Lovato et al., 2017; Oliveira et al., 2017; Celmeli et al., 2018; Yang et al., 2018; Jeepipalli et al., 2020; Liu et al., 2020; ). Therefore, regular consumption of this pulse benefits human health. The US Department of Health and Human Services (US-DHHS, 2015) recommends eating about three cups of beans like pinto, kidney, or black beans/per week because of their health benefits.

Brazil is the largest global producer of common beans, mainly for domestic consumption, with an average per capita bean consumption of $16 \mathrm{~kg}$ in 2013 (Rawal and 
Navarro, 2019). The national market in Brazil predominantly consists of two classes of beans: carioca (70\%) and black bean (20\%; Souza et al., 2020). Carioca beans are seasonally produced beans in Brazil and many other countries. So, to maintain bean supply throughout the year and prevent scarcity between harvests, the storage of this variety is crucial. However, improper storage can cause undesirable changes in the carioca beans leading to consumer rejections (Carbonell et al., 2010; Scariot et al., 2017; Alvares et al., 2020). These changes occur in the integument of some carioca bean cultivars because some genotypes darken very quickly, and the bean also hardens itself rapidly. These processes reduce the culinary quality of the carioca beans economically, depreciating the product (Bento et al., 2020a, 2020b; de Farias et al., 2020; Bento et al., 2021a).

The loss of culinary quality reduces the market value of carioca beans because consumers reject darkened grains that are considered resistant to cooking. Consequently, determinant factors in the acceptance of carioca bean cultivars are cooking time (resistance to cooking), the color of the integument, and the texture of the cooked beans. Therefore, this review aims to survey the scientific literature on factors that affect the culinary quality of carioca beans during storage.

\section{Culinary Quality}

Culinary quality of beans refers to their sensory attributes, technological properties, such as water absorption before and after cooking, cooking time or resistance to cooking, percentage of soluble solids in the broth, integument color, and the broth. Crop production, postharvest drying, and storage conditions are responsible for bean quality when it reaches its destination, either at the consumer's table or back in the field to be used as seed. Generally, beans subjected to improper handling or even storage conditions will influence the culinary quality, resulting in consumer rejection of the product.

Breeding new carioca bean cultivars emphasize high technological and cooking quality prioritizing preferential selection for lighter grains, 250-300 g 1000 seed weight, elliptical shape, semi-full degree of grain flatness, and cooking time less than 25 minutes (Kaur et al., 2009; Wani et al., 2013, 2017; Yadav et al., 2018; Ribeiro et al., 2019; ). Bean coats are rich in water-insoluble fibers and polyphenols. Their cotyledons have higher soluble fibers, oligosaccharides, and resistant starch (Singh, 2017). Hardening of the husk during bean storage occurs mainly when the air humidity is high, hindering hydration during preparation for consumption. The increased air humidity accompanied by high temperatures increases the incidence of a hardshell and hard-to-cook (HTC) grains, thereby reducing consumer's acceptance, digestibility, and protein absorption (Oliveira et al., 2011).

Briefly, $52 \%$ of surveyed consumers preferred commercial brands of carioca beans for their technological (lighter color grains [53 and 6.2; $L^{*}$ and $a^{*}$ values, respectively], medium-sized beans [ $28 \mathrm{~g}]$, elliptical shape, and semi-full flatness), cooking (fast cooking time $\sim 15 \mathrm{~min}$ ), and nutritional (high protein and minerals $[\mathrm{K}, \mathrm{P}, \mathrm{Ca}, \mathrm{Zn}$ and $\mathrm{Cu}]$ contents) quality traits (Ribeiro et al., 2019).

\section{Resistance to cooking/cooking time}

The time for beans to reach the desired degree of softness, determined as cooking time, is a critical attribute for consumers. Cooking time can also be evaluated by the resistance to cooking generally determined using the Mattson cooker (Figure 1; Proctor and Watts, 1987; Bento et al., 2020a). Freshly harvested grains have less resistance to cooking. However, when stored under ambient conditions, carioca beans increase their resistance to cooking or take longer to cook (Alvares et al., 2020; Bento et al., 2020a, 2020b; de Farias et al., 2020; Alvares et al., 2020; Bento et al., 2021a).
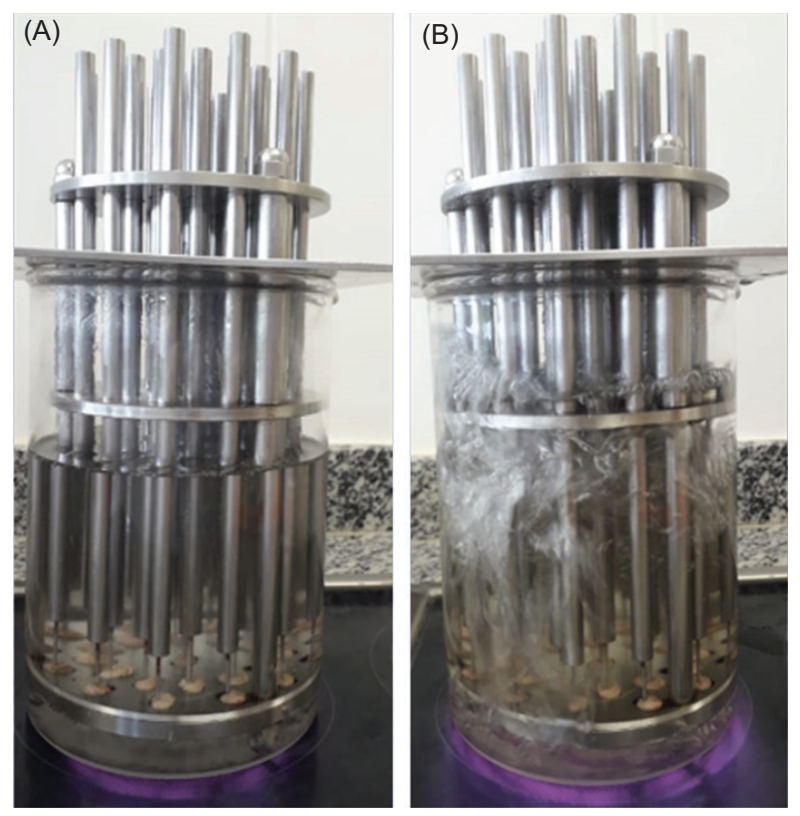

Figure 1. Mattson apparatus for bean resistance classification to cooking based on the scale defined by Proctor and Watts (1987). The time $\left(t_{13}\right)$ is recorded until the drop of the 13th rod and is converted into a rank (RMC) of resistance to cook, as described by Bento et al. (2020a). Beans in the Mattson apparatus (A). The cooking progress of beans in Mattson apparatus (B). 
Beans are soaked in water (1-12 $\mathrm{h}$ [overnight]) before cooking to reduce the cooking time. The beans are hydrated, swollen, and smooth during immersion, which reduces cooking time (Yadav et al., 2018). Immersion also promotes the uniform expansion of the seed coat and cotyledon. The extent of hydration and swelling of the grains during immersion depends on the hydration capacity of the grains and varies among different bean cultivars and is related to cooking quality (Singh et al., 2004; Kaur et al., 2009). Therefore, the bean water absorption capacity is a pivotal factor for the technical quality of the grains and is causally related to their resistance to cooking, as the cooking time decreases because of its occurrence before cooking (Kaur et al., 2009). Hence factors like the type of grain (i.e., size or shape), moisture level, genetics, storage time, and storage conditions influence the bean water absorption rate (Delfino and Canniatti-Brazaca, 2010).

The hydration kinetics of carioca beans is complex and mostly related to the seed coat. They are associated with bean composition (fat and $\mathrm{K}$ contents, protein to lipid ratio that correlates with the lag phase time) and structure (specific surface and seed coat impermeability to water; Miano et al., 2018). Alkaline conditions (pH 6-12) increase hydration kinetics (rate and water absorption) of the carioca bean (cv. IAC Eté) and reduce the lag phase (83\%), affecting the mass transfer behavior in both the seed coat and cotyledons, indicating variations in proteins and polysaccharides (Oladele et al., 2018). Hydration with ferrous sulfate $\left(\mathrm{FeSO}_{4} ; 0.271 \% \mathrm{w} / \mathrm{v}\right)$ solution accelerates carioca bean softening and cooking, particularly with ultrasound $(91 \mathrm{~W} / \mathrm{L} ; 25 \mathrm{kHz})$ at $25^{\circ} \mathrm{C}$ (Miano and Augusto, 2018). This process also fortifies the beans with iron ( $60 \mathrm{vs.} 34 \mathrm{mg} \mathrm{Fe} / 100 \mathrm{~g}$ wet basis [510 min, with and without ultrasound]). Moreover, the iron content of the seed coat, cotyledons, and whole carioca beans (cv. IAC Imperador) increased 68, 5, and 16 folds, respectively when soaked in $\mathrm{FeSO}_{4}$ solution for 510 minutes compared to conventional hydrate (distilled water) for the same time.

One of the defects (hardshell) that is observed in grains stored under conditions of inadequate temperature and humidity is alleviated bean water absorption, even after long periods of maceration. The hardshell phenomenon can be a consequence of grain storage in high humidity and high temperatures, which also causes the HTC phenomenon (Yadav et al., 2018). That refers to grains requiring a longer cooking time to soften or fail to soften even when subjected to boiling water for extended periods. Storage under ambient conditions of temperature and humidity for 6 months induces HTC phenomenon in common beans and consequently increases the cooking time. For most carioca bean cultivars, only 3 months of storage is sufficient to observe enhanced hardness (Alvares et al., 2020; Bento et al., 2020a; Alvares et al., 2021). The HTC defect manifests itself differently depending on the cultivar, planting, and storage conditions. These defects reduce the culinary quality of beans, causing depreciation and often a rejection of the product (Njoroge et al., 2015, 2016).

The HTC phenomenon has not yet been completely elucidated, despite several studies trying to understand it. Some theories have been postulated to explain the HTC phenomenon: (i) polymerization of phenolic compounds or lignification, (ii) production of insoluble pectates or phytase-phytate-pectin, (iii) changes in protein and starch, and (iv) a multiple mechanism theory (NasarAbbas et al., 2008; Siqueira et al., 2016a; Jombo et al., 2018; Siqueira et al., 2018). In the lignification theory of cotyledon tissues, the development of grain hardening is related to the polymerization of phenolic compounds, mainly from phenolic-rich seed coats. The polymerization reaction is mediated by oxido-reducing enzymes and by cross-links formation between the phenolic compounds and the cotyledon cell wall proteins (NasarAbbas et al., 2008). However, other studies by Siqueira et al. $(2014,2016 \mathrm{a}, 2018)$ showed the inadequacy of the lignification mechanism. Demonstrating that the HTC in carioca beans during storage cannot be attributed to changes in the total phenol content or the oxidoreductase activities. According to the most widely accepted "phytase-phytate-pectin" theory (Jombo et al., 2018; Yang et al., 2018), water-soluble pectin allows water absorption by legume seeds. Both phytates and carboxyl groups of soluble pectin can complex with $\mathrm{Ca}$ or $\mathrm{Mg}$ ions, but phytates preferably bind to divalent cations. If phytates complex with $\mathrm{Ca}$ or Mg ions, legume seeds are easy to cook. However, phytates can be hydrolyzed by phytase during storage, reducing their chelating potential. Then the $\mathrm{Ca}$ or $\mathrm{Mg}$ ions complexes with the carboxyl groups of the soluble pectin to form insoluble $\mathrm{Ca}$ and $\mathrm{Mg}$ pectates which are not readily dissolved when heated, thus restricting cell separation and inhibiting water absorption resulting in HTC defect (Jombo et al., 2018; Yang et al., 2018; Bento et al., 2020a). Finally, the theory that associates changes in starch during storage (Rupollo et al., 2011) was discredited. Since the noninvolvement of starch or protein in the hardening of carioca bean genotypes was known. In addition, the authors obtained results confirming that the hardening of carioca beans is related to structural changes in the cell wall and middle lamella. Genotypes susceptible to the HTC phenomenon display intense structural changes (Shiga, 2004; Siqueira et al., 2018).

\section{Integument color}

Consumers have different requirements. But generally attribute the dark color in carioca beans to prolonged 
cooking, and therefore low culinary quality (Ribeiro et al., 2008; Coelho et al., 2009; Cichy et al., 2019; Rodrigues et al., 2019; Alvares et al., 2020; Bento et al., 2020a; de Farias et al., 2020; ). According to Bolsinha de SP (Brazilian platform with bean market price information), the market negotiates the price of carioca beans, considering the color of the grain. The color is evaluated visually and subjectively based on an unofficial ascending color grade scale that ranges between 5 and 10, and in practice, the product with a grade below 8.5 is devalued (Bento et al., 2020b; Bolsinha, 2020). In short, carioca beans with dark coloring are depreciated, as they are considered of low culinary quality.

Studies generally show that the luminosity $\left(L^{*}\right)$ of the grains and the Hue angle $\left(H^{\circ}\right.$, color angle) decrease during storage and are influenced by storage time. On the other hand, the value of Chroma $\left(C^{*}\right)$, a variable that measures the opacity of the grains and the total color difference $(\Delta \mathrm{E})$, increase during storage (Siqueira et al., 2014, 2016b; Bento et al., 2020a; Coelho et al., 2020; de Farias et al., 2020;). These changes in the instrumental color parameters indicate the darkening of the carioca bean; the grains leave the cream color with brown streaks and become dark brown (Figure 2).

Changes in color parameters during storage are often associated with grain genotype, indicating that cultivars have a genetic predisposition to faster or slower browning (darkening) when stored. da Silva et al. (2008) verified that storage time accentuated the differences between quick and moderate browning carioca beans. Moreover, genotype influenced the browning/darkening rate of five carioca bean cultivars stored for 5 months under environmental conditions (Siqueira et al., 2014). In short, genotypes are sensitive to the browning process, exhibiting difference in intensity among genotypes even when stored under high relative humidity, a factor known to promote browning (Rani et al., 2013).

The rate of grain darkening is linked to the genetics of the strains, storage conditions, and storage time (Coelho et al., 2009, 2013; Rani et al., 2013; Spitti et al., 2019; de Farias et al., 2020 ). Considering that small farmers do not always have the technology or resources to invest in controlled storage of beans (under low temperature and humidity), commercial damage is inevitable, leading to the accumulation of low-value grains in the producers' warehouses, filling stations, and supermarkets. Thereby limiting the production and commercialization of good-quality beans. However, some bean genotypes that darken regardless of storage conditions do not necessarily harden or lose nutritional and functional value, and vice versa (Alvares et al., 2020; Bento et al., 2020b; de Farias et al., 2020).

The browning of stored beans has been extensively studied, although its association with culinary quality is limited in routine breeding programs (Cichy et al., 2019; Rodrigues et al., 2019; Miklas et al., 2020), which can lead to the development of apparently suitable materials in terms of appearance (color). These results in genotypes that are resistant or tolerant to factors that accelerate grain browning or darkening, but not necessarily resistance to the hardening process, masking its culinary quality (Alvares et al., 2020). Therefore, bean breeding programs must consider nutritional properties, culinary properties, and color when selecting genotypes.

\section{Texture}

Textural parameters are also used to assess the culinary quality of beans, as grain hardness or resistance

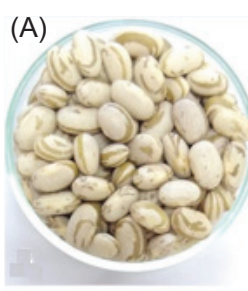

(B)
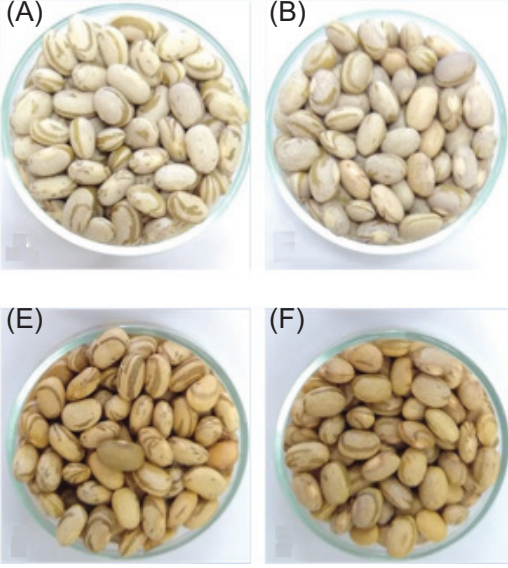

(C)

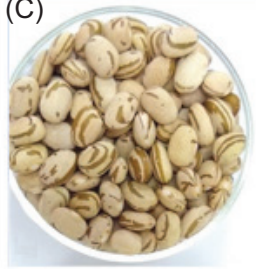

(G)

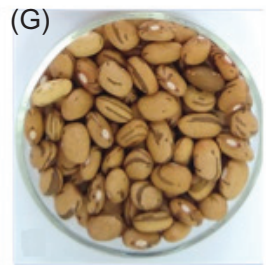

(D)
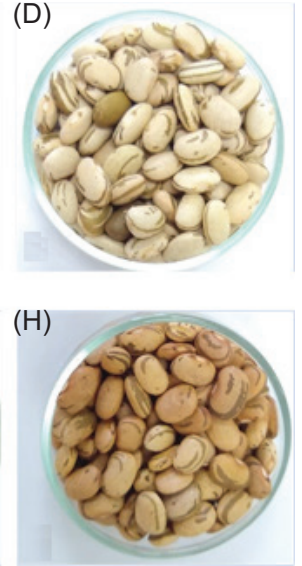

Figure 2. Freshly harvested carioca beans from slow darkening cultivar BRSMG Madrepérola (A), TAA Dama (B), darkening cultivar BRS Notable (C), and IAC Imperador (D). The corresponding grains after 6 months storage $\left(27.5 \pm 1.6^{\circ} \mathrm{C} / 56.9 \pm 10.0 \%\right.$ relative humidity- $\mathrm{RH})(\mathrm{E}-\mathrm{H})$. 
to compression strength is one of the primary sensory properties of foods. It refers entirely to the feeling of hardness that the food presents during chewing and can be objectively measured by mechanical means in fundamental units of mass or strength.

The texture parameters for beans refer to the evaluation of the hardness of raw or cooked grains, generally using the texturometer with a return-to-start analysis method that determines the strength required to compress/puncture the bean (Revilla and Vivar-Quintana, 2008; Siqueira et al. , 2013, 2014, 2016a; Bento et al., 2020a). Other studies evaluate grain texture through texture profile analysis (TPA) that provides information on hardness, cohesiveness, elasticity, gumminess, and resilience of bean samples (Koriyama and Kasai, 2019; Wani et al., 2013, 2017; Yadav et al., 2018). The best evaluation of carioca bean texture is the method that measures the force necessary to drill the grain with a $2 \mathrm{~mm}$ probe (P2) according to Revilla and Vivar-Quintana (2008) and Siqueira et al. (2013). The small area of this probe penetrates the integument. They can differentiate similar samples, even when these grains have soft cotyledons but hard integument.

The hardness of raw and cooked common beans varies (10-30 and 0.2-0.8 kgf, respectively). The texture of the cooked grains depends on the degree of cooking, and consequently if the grain is difficult to cook or exhibits HTC defect that will present greater hardness. Physical and chemical changes such as protein denaturation, carbohydrate solubilization, and starch gelatinization occur when the beans are cooked. Starch can exhibit different gelatinization patterns. Furthermore, depending on the cultivar, these changes can occur with greater or lesser intensity, favoring the reduction of grain hardness (Wani et al., 2017; Yadav et al., 2018). Moreover, Carbonell et al. (2010) associated the increase in the hardness of some cultivars with genetic characteristics of the grain or the susceptibility in the interaction of genetic and environmental factors, which can accelerate with inadequate storage.

The method of bean preparation to evaluate the texture of the cooked grain interferes with the results obtained. The difference in hardness of fresh and aged carioca beans after distilled water $(1: 2 \mathrm{w} / \mathrm{v})$ soaking $\left(18\right.$ hours, $\left.25^{\circ} \mathrm{C}\right)$ has been evaluated by five cooking methods: Mattson Bean Cooker, hot air oven, hotplate, boiling water bath, and autoclave (Siqueira et al., 2013). Generally, cooking time and temperature affect bean hardness. Mattson Bean Cooker and hot air oven undercook the beans with hardness above 4 Newtons $(\mathrm{N})$. Increasing cooking time from 30 to 60 minutes on a hotplate reduces bean hardness whereas, mild autoclave condition $\left(105^{\circ} \mathrm{C} / 10 \mathrm{~min}-\right.$ utes) differentiates fresh and aged bean hardness (3 N vs. $3.4 \mathrm{~N})$ and severe environment $\left(115{ }^{\circ} \mathrm{C} / 20\right.$ minutes $)$ produce softer beans $(0.8 \mathrm{~N}$ vs. $1 \mathrm{~N}$ for fresh and aged beans, respectively). The hotplate (45 or 60 minutes) and autoclave $\left(110{ }^{\circ} \mathrm{C} / 15\right.$ minutes) cooking promote grain softening and discriminate fresh and aged beans. Hence are, therefore, suitable procedures to prepare carioca beans for instrumental texture analyses (Marles et al., 2008). Hardness has also been used to evaluate the effects of irradiation on widely consumer accepted commercial carioca beans. Irradiation (5 kGy) almost doubled the rupture force or hardness of cooked (autoclave $121{ }^{\circ} \mathrm{C} /$ 15 minutes) carioca beans compared with nonirradiated grains. This increase in grain hardness is presumably associated with starch retrogradation after cooking (Mendes et al., 2011). Industrial canning (rotating autoclave $120{ }^{\circ} \mathrm{C}, 2$ hours/35 minutes cooking) showed no significant difference in the texture or maximum compression (90\% of initial height using $50 \mathrm{~kg}$ texture meter analyzer) force (0.60-0.75 N/grain) of carioca beans from three cultivars (Schoeninger et al., 2020).

Bean hardness increases in raw and cooked grains when stored (Siqueira et al., 2014, 2016a). This increase in hardness of aged bean is attributed to the loss of cell membrane integrity, which increases soluble solids loss in HTC grains during the immersion and cooking processes and may explain the changes in water permeability (Siqueira et al., 2013, 2014, 2016a, 2018). These results demonstrate that carioca beans hardening is related to structural changes in the cell wall and middle lamella during storage.

\section{Field Management/Environmental Influence}

The management of bean cultivation and grain harvest is the first control point for good culinary quality beans acquisition. Adverse environmental conditions, inadequate harvest time, incomplete drying, and severe threshing showed grain breakage (or the appearance of cracks in the seed coat), which favors rotting, the development of fungi, and bruchid attacks (Mutungi et al., 2020). Grains grown in tropical conditions (for example, high temperature and high humidity) may have long cooking times, and cotyledons have higher resistance to softening during cooking (Cichy et al., 2019; Kigel, 1999). Cichy et al. (2019) recommended future research to differentiate the effect of the growth and storage environment on the culinary quality of beans. In short, the growth conditions affect pests and microflora development cycles and regulate progression rates of the biochemical reactions of bean grains, thereby influencing grain quality (Mutungi et al., 2020). However, some genotypes exhibit stable cooking times in different production environments (Cichy et al., 2019).

The best harvest period for most grains is close to their physiological maturity, wherein the grains 
present maximum dry matter accumulation and quality. At this stage the grains have high (30-45\%) water contents depending on the type and cultivar (Faroni et al., 2006; Scariot et al., 2017). Thus, the grains are left in the field until they absorb water appropriate for threshing or mechanized harvesting. However, field drying can compromise grain quality since the grains are susceptible to the environmental climate, such as temperature and relative humidity variations that accelerate the respiratory rate of grains, increasing the consumption of reserves and attacks by insects and fungi. According to Scariot et al. (2017), beans harvested with $16.6 \%$ water content had lower physiological quality and 1000 seed weight than those with higher water content (25.2\% and 35.2\%). Similarly, Faroni et al. (2006) confirmed that beans harvested with $11.7 \%$ water content had lower technological classification over those with higher water content (18.7\%), demonstrating the negative effects of delayed harvest.

\section{Postharvest Management}

\section{Drying}

The reduction of water content limits the availability of water for physical-chemical and biological processes of the grains, and the development of fungi, bacteria, and insects is mainly responsible for degradation and loss during storage (Mutungi et al., 2020). Therefore, drying is extremely important before enhanced safe storage. The first stage of bean drying occurs initially at the plant itself in the field, before harvesting, and is called predrying. This is not sufficient to maintain the grain for prolong storage. Drying in the sun or at high temperatures $\left(10^{\circ} \mathrm{C}\right.$ above ambient air) under tarpaulins or land, mainly by small farmers, is carried out. Here the grain layer must not exceed $5 \mathrm{~cm}$, and periodical mixing of grains is necessary to standardize drying. This method may not reduce the water content of the grains to ideal levels or delay this process, causing losses of culinary quality in the product and are contaminated by fungi (Rani et al., 2013; Scariot et al., 2017).

The removal of water performed inappropriately by drying can negatively influence the physical, physiological, chemical, and cooking characteristics of beans. The main factors that affect the quality of the grains are the drying air temperature and the initial water content of the grains. The use of high temperatures for drying the grains, mainly combined with high water contents, can cause damage such as cracks and fissures, which can become a gateway for fungal attack during storage, in addition to reducing quality after drying (Faroni et al., 2006; Rani et al., 2013; Scariot et al., 2017). Drying beans at temperatures above $40{ }^{\circ} \mathrm{C}$ reduces their physical and physiological quality, such as 1000 seed weight, germination, and vigor (Scariot et al., 2017).

There are no current reports on drying methods that aim to reduce the loss of the culinary quality of beans. Additionally, few studies report the effects of the drying process on the organoleptic, nutritional, and culinary characteristics of the grains. However, increasing the grain drying temperature to $60^{\circ} \mathrm{C}$ increased the cooking time after 225 days of storage than the lower drying temperatures (Elias et al., 2016).

\section{Storage}

The last step before the commercialization of dry grains is storage. During this period, monitoring of some factors is pivotal to maintain bean quality and quality. While stored, grains undergo chemical and physical changes that alter their characteristics (loss of cooking quality and weight reduction). These are linked to the consumption of dry matter because of breathing and attack by pests. The absence of effective grain handling and storage techniques significantly decreases the quantity and quality of grains during the postharvest phases (Affognon et al., 2015; Mutungi et al., 2020). Hardening and reduction of the permeability of the tegument occur when grains are stored in inadequate conditions of temperature and relative humidity, increasing their resistance to cooking. These quality losses can be considered a hardshell when the tegument loses its water absorption ability and HTC when beans have increased resistance to cooking (Oliveira et al., 2011).

Temperature and relative humidity also influence grain quality during storage. The high temperature, combined with high relative humidity $(\mathrm{RH})$ of the air during storage, favors an increase in respiratory rate, culminating in accelerated deterioration rate, as well as increased fungi and insect contamination. Therefore, low temperature and relative humidity are necessary to maintain grain quality during storage (Rani et al., 2013; Coelho et al., 2020; de Farias et al., 2020). Grains stored in cold rooms $\left(8{ }^{\circ} \mathrm{C}\right.$ and $45 \% \mathrm{RH}, 360$ days) show no increase in cooking time. On the other hand, grains stored under normal environmental conditions increased their cooking time with longer storage time (Morais et al., 2010). Moreover, de Almeida et al. (2017) reported shorter cooking times in beans stored for 108 days at $15^{\circ} \mathrm{C}$ and $45 \% \mathrm{RH}$ than those stored at $27^{\circ} \mathrm{C}$ and $75 \% \mathrm{RH}$.

Some countries, such as Australia, Brazil, Africa, and Argentina, have adopted a system of hermetic storage for pulses using polyethylene (PET) silo bags. The silo bag is constructed with high-density polyethylene in three layers: two black internal layers and one white external layer 
made of titanium dioxide. The level of oxygen within the bag drastically falls, whereas carbon dioxide increases once the product is wrapped and the bag is sealed (Hell et al., 2014; Freitas et al., 2016). Thus, this technology is based on creating storage environments harmful to pests by one of the following methods: bio-generated modified atmosphere and hermetic vacuum or gas hermetic fumigation (Freitas et al., 2011; Hell et al., 2014; Mutungi et al., 2015; Freitas et al., 2016). An advantage of the hermetic silo bags is the nonchemical alternative to postharvest quality control in terms of moisture content, specific mass, germination, and electrical conductivity, for up to 120 days (Mutungi et al., 2015; Magalhaes and de Sousa, 2020). Common beans (red beans) storage in silo bags with $17.8 \%$ RH presented higher cooking time than those stored in PET bottles or a glass recipient (closed with organza fabric; Freitas et al., 2011). Information is limited on the hermetic storage using PET silo bags, silo bags with temperature control, or even PET bottles influence in cooking culinary quality of carioca beans.

\section{Type of Cultivar/Genotype}

The darkening of common beans is an undesirable characteristic for consumers, generally associated with old beans and consequently extended cooking time. However, the factors that influence darkening include environmental and genetic factors. The latter do not show any darkening pattern among different grain types and do not strongly affect the environment (Alvares et al., 2019; Spitti et al., 2019). Seed coat postharvest darkening depends on beans genotype (Islam et al., 2020).

Postharvest darkening (PHD) of seed coat gradually changes the seed coat color of some dry bean market classes during storage. Genotypic and environmental factors influence the rate and extent of PHD, and darkening occurs rapidly in environments subjected to high temperatures, humidity, and light exposure. There are at least three PHD phenotypes: (i) non-darkening (ND), (ii) slow darkening (SD), and (iii) regular darkening (RD). SD and ND genotypes have already been identified in common beans (Elsadr et al., 2011).

According to Spitti et al. (2019), darkening is closely linked to the growing environment regardless of the cultivated genotype, or the genotype and environment interaction affect the bean seed coat darkening, requiring the characteristic evaluation in various climates of genetic control and strains selection (Silva et al., 2014). Seed coat darkening and cooking resistance increased in different carioca bean genotypes over 6 months of storage under varied environmental conditions (Siqueira et al., 2014).

\section{Darkening gene}

Genetic variation occurs in seed coat darkening of many bean classes including carioca beans (Rodrigues et al., 2019). The variation can be monogenic or oligogenic, which means their inheritance is controlled by one or a few genes (Silva et al., 2018). In carioca beans, the darkening phenotype is controlled by a single recessive gene "Sd", the slow darkening is represented by the "sd" recessive allele (Silva et al., 2008). However, oligogenic control has also been proposed (Elsadr et al., 2011; Silva et al., 2014). A model with two genes interacting under epistasis was suggested by Elsadr et al. (2011), where the "J" gene modulates darkening or interacts with a second $\mathrm{Sd}$ gene, responsible for regulating the darkening rate. Similarly, Spitti et al. (2019) described that this characteristic is oligogenic or even polygenic from significant results obtained by the genotype and environment interaction.

Islam et al. (2020) demonstrated yet another allele in the $\mathrm{P}$ gene (Psd) responsible for the SD trait in common beans, "P" is a transcription factor that restores the seed coat color. The sequence comparison of this gene in several beans differing in the seed coat postharvest darkening provided insights into the molecular mechanism that governs this characteristic and the development of new specific gene markers for potential use in bean breeding programs. Selecting lines with slow seed coat darkening is possible despite conflicting results regarding the control of beans darkening (Silva et al., 2014). However, selection based on the evaluation of only one environment can generate sufficient gains for this characteristic, even in the presence of genotype and environment interaction, which would explain the inconsistencies between the patterns of genetic control in each location (Alvares et al., 2016).

The elucidation of the genetic control of grain darkening is of fundamental importance to establish breeding programs for developing cultivars with slow seed coat darkening during storage (Silva et al., 2014). Microsatellites are notable in genetic diversity studies. Polymerase chain reaction (PCR)-based markers are developed for a many plant species, including commercial crops. A panel of 24 microsatellites has been built for the common bean specifically for studying the genetic diversity available to the scientific community and has been routinely used for this type of analysis in Brazil (Métais et al., 2002; Blair et al., 2003; Morais et al., 2016). Thousands of single nucleotide polymorphism markers are currently available for the common bean. This number increased immensely because of the species genome sequence publication (Phaseolus vulgaris v1.0; http://www.phytozome. net; Schmutz et al., 2014; Morais et al., 2016). Even if the choice of breeding lines and the development of cultivars 
with the slow darkening trait are relatively simple, given its high heritability and simple genetics, the genetic complexity of many interesting characteristics makes this selection difficult in breeding programs. However, the slow darkening trait is expressed maternally and inherited recessively (Silva et al., 2018; Alvares et al., 2019).

\section{Oxidative Enzymes Related to Beans Aging}

During storage, cell damage occurs with advanced grain aging, and the physical barrier that separates enzymes and substrates is lost, enabling the oxidation of phenolic compounds by oxidoreductases. Complex processes and enzymatic reactions are activated in postharvest beans and intensify during storage, initiating the aging and darkening phenomenon (Siqueira et al., 2016b). Postharvest darkening of the bean seed coat, both enzymatic and nonenzymatic, has already been attributed to the presence of phenolic compounds (Spitti et al., 2019) because of their involvement in oxidative steps and subsequent changes in the flavonoid skeleton, as well as by the formation of quinones or similar enzyme-mediated reactions (Marles et al., 2008; Siqueira et al., 2016b; Bento et al., 2021a).

Polyphenol oxidase is associated with the enzymatic activity of peroxidase. It produces a dark compound that causes grain integument darkening called melanin (Siqueira et al., 2016b). RD is strongly associated with increased polyphenol oxidase activity in some strains of beans (Marles et al., 2008). Likewise, Alves et al. (2021) evaluating, a fast darkening and hardening cultivar that demonstrated high peroxidase and polyphenol oxidase activity in the process. Higher polyphenol oxidase activity is noted in bean cultivars with lighter tegument than in dark tegument cultivars during the complete aging process. This activity confirms that oxidative processes of phenolic compounds linked to polyphenol oxidase activity contribute to color changes in the bean grain coat (Siqueira et al., 2016b). Polyphenol oxidase and peroxidase activities are attenuated during controlled bean storage at cooling temperature, thereby inhibiting/suppressing grain darkening (Demito et al., 2019). Therefore, the highest color change occurs at higher storage temperatures because of high enzymatic activity, mainly polyphenol oxidase, which degrades polyphenols and reduces the bioactive value of these grains.

Oxidation by environmental oxygen can trigger the darkening and hardening process of carioca beans. Previous research by Bento et al. (2020a) found the predominant superoxide dismutase (SOD) activity in the grain integument. But its byproduct, hydrogen peroxide, was only noted in the integument. The high SOD activity suggests that the seed tissue (like cotyledons) maintains strict airway control. Another study by Siqueira et al. (2016b) also stressed the importance of analyzing the separate cotyledon integument because of these enzyme variations activities. Nevertheless, according to Bento et al. (2020a), the presence and activity of SOD indicate that oxidative stress occurs during storage.

The hardening of beans during storage is also related to low humidity and hydration defects. High temperatures and low relative humidity in the presence of light and oxygen are the main factors that hinder water absorption, in which shows grain hardening consequently, contributing to the HTC phenomenon because of changes in phenolic content related to lignification and loss of phytates (Junk-Knievel et al., 2008). The lignification process relates the hardening with the polymerization of the phenolic compounds from the integument, mediated by polyphenol oxidases, and the formation of cross-links between phenolic compounds and cell wall proteins of the cotyledon. Peroxidase is involved in the polymerization reaction of phenolic compounds. An increase in its activity may be associated with the cell wall lignification process (Alves et al., 2021). The hardening process can also be explained by the SOD activity in oxidative stress (Bento et al., 2020a).

\section{Polyphenolic Compounds}

Polyphenolic compounds are associated with the plant defense system, ensuring resistance to pest attacks at considerable levels but, they can accelerate the grain darkening process (Spitti et al., 2019). According to Chen et al. (2015), bean darkening is rapid and more common in cultivars with high phenolic content in the tegument. Other studies have also associated bean darkening to the content of phenolic compounds, where darkening is more prevalent in cultivars with high phenolic content in the tegument, and the degree of darkening is proportional to the loss of phenolics (Martín-Cabrejas et al., 1997; Beninger et al., 2005; Luthria and Pastor-Corrales, 2006; Nasar-Abbas et al., 2009). In a recent study, the content of phenolic compounds decreased for fast darkening grains but did not change or increased in slow darkening carioca beans during storage (Bento et al., 2021a). Furthermore, kaempferol was suggested as the marker to differentiate fast and slow darkening cultivars since it decreased in quick darkening cultivars during storage.

The bean darkening has also been associated with the presence of proanthocyanidins (condensed tannins) in the seed coat (Junk-Knievel et al., 2007), which accumulate at higher levels in regular darkening than in the slow darkening genotypes, just like most flavonoids (Duwadi et al., 2018). Proanthocyanidins are oligomeric flavonoids composed mainly of catechin and epicatechin 
units. The synthesis of proanthocyanidin shares the flavonoids pathway with anthocyanins to leukocyanidin/ cyanidin (Duwadi et al., 2018). The presence of catechin and kaempferol was identified by Beninger et al. (2005), and the significant increase in aging suggesting that the formation of these compounds occurred during the oxidative process. Therefore, these compounds can interfere with the culinary quality of beans once the dimer procyanidin B-type contributes to the seed coat darkening process because of the oxidation of proanthocyanidin in reactive quinones (brown colored compound; Ranilla et al., 2007; Bento et al., 2021a).

\section{Alternative Uses of Beans with Low Culinary Quality}

The aged beans with low culinary quality and consequently low commercial value can be used as ingredients in food formulation. In the same way, bean byproducts (i.e., broken beans) may be used for food development since they present similar nutritional value compared with whole grains. Both can be transformed into flours that constitute a new way of using materials with low added value that can contribute to the sustainability of the bean production chain. The bean flour usage is aligned with the current trends and consumption habits, based on sensory quality, practicality, diversity, and healthiness. Bean flours can also be used in the gluten-free and vegan products development, one of the most successful markets in the food industry. Thus, various studies report an effective way to apply aged dry beans flour as a base ingredient in many foods, such as tempeh (Bento et al., 2020c), baked snacks (tortillas), and instant pasta (Bento et al., 2021b), vegan tempeh burger (Bento et al., 2021c), mix for cakes (Gomes et al., 2015; Bassinello et al., 2020). In these studies, the aged beans were heat treated (e.g., extrusion, cooking in an autoclave, or the traditional pressure-cooking method) to mitigate some unpleasant flavors in the bean flours (Pasqualone et al., 2020).

Other studies have also used bean as ingredient for the development of spaghetti and ravioli (Gallegos-Infante et al., 2010; Ringuette et al., 2018), extruded snacks (Bassinello et al., 2015), light red kidney bean porridge (Nyombaire et al., 2011), snack bars (Ramírez-Jiménez et al., 2018), cookies (Pérez-Ramírez et al., 2018), bread and chips (Hooper et al., 2019), and extruded snacks made with maize and bean (7:3; Félix-Medina et al., 2021). In addition, there is significant interest presently in dry and wet fractionation of pulses into starch, protein, and fiber concentrates for use in both food and nonfood products (Tyler et al., 2017). Additionally, the consumption of bean products is associated with health benefits such as the reduced risk for cardiovascular disease and cancer, the management of type 2 diabetes, metabolic syndrome, and obesity, and contributes to overall health and wellness (Tyler et al., 2017; de Lima et al., 2019; Mullins and Arjmandi, 2021).

\section{Conclusion}

The culinary quality of beans is influenced by intrinsic and extrinsic factors and involves sensory attributes and technological properties that directly reflect consumer choice. The cooking time, color, and texture are the determining properties in the acceptance of the grain, which can be affected during storage mainly by temperature and humidity. The type of cultivar directly influences the darkening and hardening of the grain. The literature presents this control as oligogenic or monogenic. Moreover, different cultivars have a varied genetic makeup for darkening. Specific phenolic compounds present in the tegument play an important role as a substrate for oxidation reactions, and the type of pigments determine the final color of the grain, that is, the post-harvest darkening rate. The future perspectives to enhance bean quality may be related to the use of different techniques for enhanced preservation of the grains appearance and composition, such as the system of hermetic storage using polyethylene silo bags. Additionally, the breeding programs can recommend new bean cultivars in the market, which are resistant to long-term storage without losing their culinary quality. A study of factors influencing bean properties acceptable by the final consumer is critical to encourage breeding programs and increase the demand for this high nutritional food. The use of bean flour as a food ingredient is an alternative for the use of aged beans with low culinary quality and improves food industry diversity. In addition, they are the excellent raw material for protein extraction in plant-based products applications, a market that has been growing in recent years. Additionally, aged beans or broken grains have potential for use in gastronomy (as flour) because of their technological, nutritional, and functional properties, as well as their versatile application. It is also an option to enrich school meals and the diet of low-income populations, in addition to specific demands (gluten-free, low glycemic index, vegan, etc.).

\section{References}

Affognon H., Mutungi C., Sanginga P. and Borgemeister C., 2015. Unpacking postharvest losses in sub-Saharan Africa: a meta-analysis. World Dev. 66: 49-68. https://doi.org/10.1016/j. worlddev.2014.08.002

Alvares R., Pereira H., Melo L., Miklas P. and Melo P., 2020. Induction of seed coat darkening in common beans (Phaseolus vulgaris L.) and the association with cooking time after storage. Aus. J. Crop Sci. 14: 21-27. https://doi.org/10.21475/ajcs.20.14.01.p1500 
Alvares R.C., Silva F.C., Melo L.C., Melo P. and Pereira H.S., 2016. Estimation of genetic parameters and selection of high-yielding, upright common bean lines with slow seed-coat darkening. Genet. Mol. Res. 15(4). https://doi.org/10.4238/gmr15049081

Alvares R.C., Stonehouse R., Souza T.L.P.O., Melo P.G.S., Miklas P.N., Bett K.E., Melo L.C., et al., 2019. Generation and validation of genetic markers for the selection of carioca dry bean genotypes with the slow-darkening seed coat trait. Euphytica. 215(8): 141. https://doi.org/10.1007/s10681-019-2461-y

Alves N.E.G., Gomes M.J.C., Vasconcelos C.M., Lima A.C., de Lima S.L.S. Brito E.S., et al., 2021. Six months under uncontrolled relative humidity and room temperature changes technological characteristics and maintains the physicochemical and functional properties of carioca beans (Phaseolus vulgaris L.). Food Chem. 342: 128390. https://doi.org/10.1016/j. foodchem.2020.128390

Bassinello P.Z., Bento J.A.C., Gomes L.d.O.F., Caliari M. and Oomah B.D., 2020. Nutritional value of gluten-free rice and bean based cake mix. Ciênc. Rural 50(6). https://doi. org/10.1590/0103-8478cr20190653

Bassinello P.Z., Carvalho A.V., Rios A.d.O., Maciel R.d.A. and Berrios J.D.J., 2015. Expanded gluten-free extrudates made from rice grits and bandinha (Bean) flour mixes: main quality properties. J. Food Process. Preserv. 39(6): 2267-2275. https://doi. org/10.1111/jfpp.12472

Beninger C.W., Gu L., Prior R.L., Junk D.C., Vandenberg A. and Bett K.E., 2005. Changes in polyphenols of the seed coat during the after-darkening process in pinto beans (Phaseolus vulgaris L.). J. Agric. Food Chem. 53(20): 7777-7782. https://doi. org/10.1021/jf0500511

Bento J.A.C., Bassinello P.Z., Colombo A.O., Vital R.J. and Carvalho R.N., 2020c. Nutritional and bioactive components of carioca common bean (Phaseolus vulgaris L.) tempeh and yellow soybean (Glycine max L.) tempeh. Curr. Nutr. Food Sci. 16: 1-8. https://doi.org/10.2174/1573401316666200121111854.

Bento J.A.C., Bassinello P.Z., Colombo A.O., Vital R.J. and Carvalho R.N., 2021c. Vegan tempeh burger: prepared with aged bean grains fermented by Rhizopus oligosporus inoculum. Res. Soc. Dev. 10(2): e38110212503. https://doi.org/10.33448/ rsd-v10i2.12503

Bento J.A.C., Bassinello P.Z., de Cruz Q.A., Mendonça M.A.D.S., Borba T.C.d.O., Vanier N.L., et al., 2020b. Convenience of non-conventional methods for evaluation of the culinary quality of beans. Res. Soc. Dev. 9(11): e44491110103. https://doi. org/10.33448/rsd-v9i11.10103

Bento J.A.C., Bassinello P.Z., Morais D.K., de Souza NetoM.A., Bataus L.A.M., Carvalho R.N., et al., 2021b. Pre-gelatinized flours of black and carioca bean by-products: development of glutenfree instant pasta and baked snacks. International J. Gastron. Food Sci. 25: 100383. https://doi.org/10.1016/j.ijgfs.2021.100383

Bento J.A.C., Lanna A.C., Bassinello P.Z., Oomah B.D., Pimenta M.E.B., Carvalho R.N. et al., 2020a. Aging indicators for stored carioca beans. Food Res. Int. 134(109249): 1-11. https:// doi.org/10.1016/j.foodres.2020.109249

Bento J.A.C., Ribeiro P.R.V., Bassinello P.Z., de Brito E.S., Zocollo G.J., Caliari M. et al., 2021a. Phenolic and saponin profile in grains of carioca beans during storage. LWT. 139: 110599. https://doi.org/10.1016/j.lwt.2020.110599

Blair M.W., Pedraza F., Buendia H.F., Gaitán-Solís E., Beebe S.E., Gepts P. et al., 2003. Development of a genome-wide anchored microsatellite map for common bean (Phaseolus vulgaris L.). Theor. Appl. Genet. 107(8): 1362-1374. https://doi.org/10.1007/ s00122-003-1398-6

Bolsinha, 2020. Bean newsletter. Available at: https://www.bolsinha. com.br/br/default.asp

Carbonell S.A.M., Chiorato A.F., Gonçalves J.G.R., Perina E.F. and Carvalho C.R.L., 2010. Tamanho de grão comercial em cultivares de feijoeiro. Ciênc. Rural 40: 2067-2073. https://doi. org/10.1590/S0103-84782010005000159

Celmeli T., Sari H., Canci H., Sari D., Adak A., Eker T., et al., 2018. The nutritional content of common bean (Phaseolus vulgaris L.) landraces in comparison to modern varieties. Agronomy. 8(9): 1-9. https://doi.org/10.3390/agronomy8090166

Chen P.X., Bozzo G.G., Freixas-Coutin J.A., Marcone M.F., Pauls P.K., Tang Y., et al., 2015. Free and conjugated phenolic compounds and their antioxidant activities in regular and non-darkening cranberry bean (Phaseolus vulgaris L.) seed coats. J. Funct. Foods. 18: 1047-1056. https://doi.org/10.1016/j. jff.2014.10.032

Cichy K.A., Wiesinger J.A., Berry M., Nchimbi-Msolla S., Fourie D., Porch T.G., et al., 2019. The role of genotype and production environment in determining the cooking time of dry beans (Phaseolus vulgaris L.). Legum. Sci. 1(1): e13. https://doi. org/10.1002/leg3.13

Coelho S.R.M., Alves Filho E.G., Silva L.M.A., Bischoff T.Z., Ribeiro P.R., Zocolo G.J., et al., 2020. NMR and LC-MS assessment of compound variability of common bean (Phaseolus vulgaris) stored under controlled atmosphere. LWT. 117: 108673. https://doi.org/10.1016/j.lwt.2019.108673

Coelho S.R.M., Prudencio S.H., Christ D., Sampaio S.C. and Schoeninger V., 2013. Physico-chemical properties of common beans under natural and accelerated storage conditions. Cienc. Investig. Agrar. 40(3): 629-636. https://doi.org/10.4067/ s0718-16202013000300015

Coelho S.R.M., Prudencio S.H., Nóbrega L.H.P. and Leite C.F.R., 2009. Alterações no tempo de cozimento e textura dos grãos de feijão comum durante o armazenamento. Ciênc. Agrotecnologia. 33(2): 539-544. https://doi.org/10.1590/S1413-70542009000200028

da Silva G.S., Ramalho M.A.P., Abreu A. and Silva F.B., 2008. Genetic control of early grain darkening of carioca common bean. Crop Breed. Appl. Biotechnol. 8(4): 299-304. https://doi. org/10.12702/1984-7033.v08n04a07

de Almeida A.J.B., Coelho, S.R.M., Schoeninger, V. and Christ, D., 2017. Chemical changes in bean grains during storage in controlled conditions. Eng. Agríc. 37: 529-540. https://doi. org/10.1590/1809-4430-eng.agric.v37n3p529-540/2017

de Farias H.F.L., Devilla I.A., Silva A.P., Bento J.A.C. and Bassinello P.Z., 2020. Modeling the color and hardness of beans according to storage conditions. Res. Soc. Dev. 9(7): e725974414. https://doi.org/10.33448/rsd-v9i7.4414

de Lima S.L.S., Gomes M.J.C., da Silva B.P., Alves N.E.G., Toledo R.C.L., Theodoro J.M.V., et al. 2019. Whole flour and 
protein hydrolysate from common beans reduce the inflammation in BALB/C mice fed with high fat high cholesterol diet. Food Res. Int. 122: 330-339. https://doi.org/10.1016/j. foodres.2019.04.013

Delfino R.d.A. and Canniatti-Brazaca S.G., 2010. Polyphenol and protein interaction and the effect on protein digestibility in common bean (Phaseolus vulgaris L.) cultivar Perola. Food Sci. Technol. 30(2): 308-312. https://doi.org/10.1590/S0101-20612010000200003

Demito A., Ziegler V., Goebel J.T.S., Konopatzki E.A., Coelho S.R.M. and Elias M.C., 2019. Effects of refrigeration on biochemical, digestibility, and technological parameters of carioca beans during storage. J. Food Biochem. 43(7): e12900. https:// doi.org/10.1111/jfbc.12900

Duwadi K., Austin R.S., Mainali H.R., Bett K., Marsolais F. and Dhaubhadel S., 2018. Slow darkening of pinto bean seed coat is associated with significant metabolite and transcript differences related to proanthocyanidin biosynthesis. BMC Genomics. 19(1): 260. https://doi.org/10.1186/s12864-018-4550-z

Elias M.C., Ziegler V., Romano C.M., Alves G.H., Paraginski R.T. and de Oliveira M., 2016. Physicochemical properties and enzymatic bean grains dried at different temperatures and stored for 225 days. Semina: Ciênc. Agrár. 37(3): 1295-1305. https://doi. org/10.5433/1679-0359.2016v37n3p1295

Elsadr H.T., Wright L.C., Peter Pauls K. and Bett K.E., 2011. Characterization of seed coat post harvest darkening in common bean (Phaseolus vulgaris L.). Theor. Appl. Genet. 123(8): 1467-1472. https://doi.org/10.1007/s00122-011-1683-8

FAO. 2019. Food and Agriculture Organization of the United Nations. FAOSTAT Crops. Available at: http://www.fao.org/ faostat/en/\#data/QC.

Faroni L.R.A., Cordeiro I.C., Alencar E.R.d., Rozado A.F. and Alves W.M. 2006. Influence of the harvest moisture content and of the drying temperature upon the bean quality. Rev. Bras. Eng. Agric. Ambient. 10(1): 148-154. https://doi.org/10.1590/ S1415-43662006000100022

Félix-Medina J.V., Gutiérrez-Dorado R., López-Valenzuela J.A., López-Ángulo G., Quintero-Soto M.F., Perales-Sánchez J.X.K. and Montes-Ávila J., 2021. Nutritional, antioxidant and phytochemical characterization of healthy ready-to-eat expanded snack produced from maize/common bean mixture by extrusion. LWT. 142: 111053. https://doi.org/10.1016/j. lwt.2021.111053

Freitas R.d.S., Faroni L.R., Sousa A.H., Cecon P.R. and Carvalho M.S., 2011. Quality of beans stored under hermetic conditions. J. Eng. Agríc. 31(6): 1136-1149. https://doi.org/10.1590/ S0100-69162011000600011

Freitas R.S., Faroni L.R.A. and Sousa A.H., 2016. Hermetic storage for control of common bean weevil, Acanthoscelides obtectus (Say). J. Stored Prod Res 66: 1-5. https://doi.org/10.1016/j. jspr.2015.12.004

Gallegos-Infante J. A., Bello-Perez L.A., Rocha-Guzman N.E., Gonzalez-Laredo R.F. and Avila-Ontiveros M., 2010. Effect of the addition of common bean (Phaseolus vulgaris L.) flour on the In Vitro digestibility of starch and undigestible carbohydrates in Spaghetti. J. Food Sci. 75(5): H151-H156. https://doi. org/10.1111/j.1750-3841.2010.01621.x
Ganesan K. and Xu B., 2017. Polyphenol-rich dry common beans (Phaseolus vulgaris L.) and their health benefits. Int. J. Mol. Sci. 18(11): 2331. https://doi.org/10.3390/ijms18112331

Gomes L.D.F., Santiago R.D.C., Carvalho A.V., Carvalho R.N., de Oliveira I.G. and Bassinello P.Z., 2015. Application of extruded broken bean flour for formulation of gluten-free cake blends. Food Sci. Technol. 35(2): 307-313. https://doi. org/10.1590/1678-457x.6521

Hell K., Edoh Ognakossan K. and Lamboni Y., 2014. PICS hermetic storage bags ineffective in controlling infestations of Prostephanus truncatus and Dinoderus spp. in traditional cassava chips. J Stored Prod. Res. 58: 53-58. https://doi. org/10.1016/j.jspr.2014.03.003

Hooper S.D., Glahn R.P. and Cichy K.A., 2019. Single varietal dry bean (Phaseolus vulgaris L.) pastas: nutritional profile and consumer acceptability. Plant Foods Hum. Nutr. 74(3): 342-349. https://doi.org/10.1007/s11130-019-00732-y

Islam N.S., Bett K.E., Pauls K.P., Marsolais F. and Dhaubhadel S. 2020. Postharvest seed coat darkening in pinto bean (Phaseolus vulgaris) is regulated by Psd, an allele of the basic helix-loophelix transcription factor P. Plants People Planet 2(6): 663-677. https://doi.org/10.1002/ppp3.10132

Jeepipalli S.P.K., Du B., Sabitaliyevich U.Y. and Xu B., 2020. New insights into potential nutritional effects of dietary saponins in protecting against the development of obesity. Food Chem. 318: 126474. https://doi.org/10.1016/j.foodchem.2020.126474.

Jombo T.Z., Minnaar A. and Taylor J.R.N., 2018. Effects of gammairradiation on cotyledon cell separation and pectin solubilisation in hard-to-cook cowpeas. J. Sci. Food Agric. 98(5): 1725-1733. https://doi.org/10.1002/jsfa.8645

Junk-Knievel D.C., Vandenberg A. and Bett K.E., 2007. An accelerated postharvest seed-coat darkening protocol for pinto beans grown across different environments. Crop Sci. 47(2): 694-700. https://doi.org/10.2135/cropsci2006.05.0325

Junk-Knievel D.C., Vandenberg A. and Bett K.E., 2008. Slow darkening in pinto bean (Phaseolus vulgaris L.) seed coats is controlled by a single major gene. Crop Sci. 48(1): 189-193. https://doi. org/10.2135/cropsci2007.04.0227

Kaur S., Singh N., Sodhi N.S. and Rana J.C., 2009. Diversity in properties of seed and flour of kidney bean germplasm. Food Chem. 117(2): 282-289. https://doi.org/10.1016/j. foodchem.2009.04.002

Kigel J. 1999. Culinary and nutritional quality of Phaseolus vulgaris seeds as affected by environmental factors. Biotechnol. agron. soc. environ. 3(4).

Koriyama T. and Kasai M., 2019. Effect of pre-soaking treatment on softening and hardening during cooking of stored beans. Food Sci. Technol, Res. 25(3): 425-434. https://doi.org/10.3136/ fstr.25.425

Liu Y., Ragaee S., Marcone M.F. and Abdel-Aal E.S.M., 2020. Effect of different cooking methods and heating solutions on nutritionally-important starch fractions and flatus oligosaccharides in selected pulses. Cereal Chem. 97(6): 1216-1226. https:// doi.org/10.1002/cche.10344.

Lovato F., Kowaleski J., Silva S.Z.d. and Heldt L.F.S., 2017. Composição centesimal e conteúdo mineral de diferentes cultivares de feijão 
biorfortificado (Phaseolus vulgaris L.). Braz. J. Food Technol. 21. https://doi.org/10.1590/1981-6723.6817

Luthria D.L. and Pastor-Corrales M.A., 2006. Phenolic acids content of fifteen dry edible bean (Phaseolus vulgaris L.) varieties. J. Food Compos. Anal. 19(2): 205-211. https://doi.org/10.1016/j. jfca.2005.09.003

Magalhaes V.B. and de Sousa A.H., 2020. Quality of white Gurgutuba creole beans stored in silo bags and PET bottles. Rev. Agrogeoambiental 12(3). https://doi.org/10.18406/2316-1817v12n320201465

Marles M.A., Vandenberg A. and Bett K.E., 2008. Polyphenol oxidase activity and differential accumulation of polyphenolics in seed coats of pinto bean (Phaseolus vulgaris L.) characterize postharvest color changes. J Agric. Food Chem. 56(16): 70497056. https://doi.org/10.1021/jf8004367

Martín-Cabrejas M.A., Esteban R.M., Perez P., Maina G. and Waldron K.W., 1997. Changes in physicochemical properties of dry beans (Phaseolus vulgaris L.) during long-term storage. J Agric. Food Chem. 45(8): 3223-3227. https://doi.org/10.1021/ jf970069z

Mendes N.S., Silva Y., Tiraboschi P.C., Takeuchi K.P., Souza A.R. and Arthur V., 2011. Evaluation of the texture of beans (Phaseolus vulgaris L.) of the variety carioca treated by gamma irradiation process, 2011 International Nuclear Atlantic Conference-INAC 2011, Belo Horizonte, MG, Brazil. Available from: https://inis.iaea.org/collection/NCLCollectionStore/_ Public/43/056/43056419.pdf.

Métais I., Hamon B., Jalouzot R. and Peltier D., 2002. Structure and level of genetic diversity in various bean types evidenced with microsatellite markers isolated from a genomic enriched library. Theor Appl Genet 104(8): 1346-1352. https://doi.org/10.1007/ s00122-002-0901-9

Miano A.C. and Augusto P.E.D., 2018. The ultrasound assisted hydration as an opportunity to incorporate nutrients into grains. Food Res. Int. 106: 928-935. https://doi.org/10.1016/j. foodres.2018.02.006

Miano A.C., Saldaña E., Campestrini L.H., Chiorato A.F. and Augusto P.E.D., 2018. Correlating the properties of different carioca bean cultivars (Phaseolus vulgaris) with their hydration kinetics. Food Res. Int. 107: 182-194. https://doi.org/10.1016/j. foodres.2018.02.030

Miklas P.N., Osorno J.M., Chaves B. and Cichy K.A., 2020. Agronomic performance and cooking quality characteristics for slow-darkening pinto beans. Crop Sci. 60(5): 2317-2327. https://doi.org/10.1002/csc2.20220

Morais P.P.P., Valentini G., Guidolin A.F., Baldissera J.N.d.C. and Coimbra J.L.M., 2010. Influence of the period and storage conditions of beans at the time of cooking. Revista Ciênc Agron. 41(4): 593-598. https://doi.org/10.1590/S1806-66902010000400011

Morais S., Vieira A., Almeida L., Rodrigues L., Melo P., Faria L., et al., 2016. Application of microsatellite markers to confirm controlled crosses and assess genetic identity in common bean. Crop. Breed. Appl. Biotechnol. 16: 234-239. https://doi. org/10.1590/1984-70332016v16n3n35

Mullins A.P. and Arjmandi B.H., 2021. Health benefits of plantbased nutrition: focus on beans in cardiometabolic diseases. Nutrients 13(2). https://doi.org/10.3390/nu13020519
Mutungi C., Affognon H.D., Njoroge A.W., Manono J., Baributsa D. and Murdock L.L., 2015. Triple-layer plastic bags protect dry common beans (Phaseolus vulgaris) against damage by acanthoscelides obtectus (Coleoptera: Chrysomelidae) during storage. J. Econ. Entomol. 108(5): 2479-2488. https://doi.org/10.1093/ jee/tov197

Mutungi C., Chamwilambo M., Masanja S., Massam C., Wayda P., Tungu J., et al., 2020. Quality and storability of common beans in small-holders farm stores in Northern Tanzania: a multivariate analysis of agro-location, variety, and storage method effects. J. Stored Prod. Res. 89: 101723. https://doi.org/10.1016/j. jspr.2020.101723

Nasar-Abbas S.M., Plummer J.A., Siddique K.H.M., White P., Harris D. and Dods K., 2008. Cooking quality of faba bean after storage at high temperature and the role of lignins and other phenolics in bean hardening. LWT.41(7): 1260-1267. https:// doi.org/10.1016/j.lwt.2007.07.017

Nasar-Abbas S.M., Siddique K.H.M., Plummer J.A., White P.F., Harris D., Dods K. and D’Antuono M., 2009. Faba bean (Vicia faba L.) seeds darken rapidly and phenolic content falls when stored at higher temperature, moisture and light intensity. LWT-Food Sci. Technol. 42(10): 1703-1711. https://doi. org/10.1016/j.lwt.2009.05.013

Njoroge D.M., Kinyanjui P.K., Chigwedere C.M., Christiaens S., Makokha A.O., Sila D.N., et al., 2016. Mechanistic insight into common bean pectic polysaccharide changes during storage, soaking and thermal treatment in relation to the hard-to-cook defect. Food Res. Int. 81: 39-49. https://doi.org/10.1016/j.foodres.2015.12.024

Njoroge D.M., Kinyanjui P.K., Christiaens S., Shpigelman A., Makokha A.O., Sila D.N. et al., 2015. Effect of storage conditions on pectic polysaccharides in common beans (Phaseolus vulgaris) in relation to the hard-to-cook defect. Food Res Int. 76: 105-113. https://doi.org/10.1016/j.foodres.2015.03.005

Nyombaire G., Siddiq M. and Dolan K.D., 2011. Physico-chemical and sensory quality of extruded light red kidney bean (Phaseolus vulgaris L.) porridge. LWT.-44(7): 1597-1602. https://doi. org/10.1016/j.lwt.2011.02.016

Oladele S.O., Osundahunsi O.F., Agbetoye L.A.S. and Augusto P.E.D., 2018. Hydration kinetics of carioca beans at different pHs. J. Food Process Eng. 41(8): e12908. https://doi. org/10.1111/jfpe.12908

Oliveira L.C., Lima D.C.N., Bailoni M.A., Risso E.M., Schmiele M., Steel C.J. et al., 2017. Physical characteristics, nutritional quality, and antioxidant potential of extrudates produced with polished rice and whole red bean flours. Cereal Chem. 94(1): 74-81. https://doi.org/10.1094/cchem-05-16-0129-fi

Oliveira V.R.d., Ribeiro N.D., Maziero S.M., Cargnelutti Filho A. and Jost E., 2011. Cooking quality and nutritional composition of common bean genotypes with and without stored refrigeration. Ciênc. Rural 41(5): 746-752. https://doi.org/10.1590/ S0103-84782011005000050

Pasqualone A., Costantini M., Coldea T.E. and Summo C., 2020. Use of legumes in extrusion cooking: a review. Foods 9(7). https:// doi.org/10.3390/foods9070958

Pérez-Ramírez I.F., Becerril-Ocampo L.J., Reynoso-Camacho R., Herrera M.D., Guzmán-Maldonado S.H. and Cruz-Bravo R.K., 
2018. Cookies elaborated with oat and common bean flours improved serum markers in diabetic rats. J. Sci. Food Agric. 98(3): 998-1007. https://doi.org/10.1002/jsfa.8548

Proctor J.R. and Watts B.M., 1987. Development of a modified mattson bean cooker procedure based on sensory panel cookability evaluation. Can. Inst. Food Technol. J. 20(1): 9-14. https://doi.org/10.1016/s0315-54.63(87)70662-2

Ramírez-Jiménez A.K., Gaytán-Martínez M., Morales-Sánchez E. and Loarca-Piña G., 2018. Functional properties and sensory value of snack bars added with common bean flour as a source of bioactive compounds. LWT. 89: 674-680. https://doi. org/10.1016/j.lwt.2017.11.043

Rani P.R., Chelladurai V., Jayas D.S., White N.D.G. and KavithaAbirami C.V., 2013. Storage studies on pinto beans under different moisture contents and temperature regimes. J Stored Prod. Res. 52: 78-85. https://doi.org/10.1016/j.jspr.2012.11.003

Ranilla L.G., Genovese M.I. and Lajolo F.M., 2007. Polyphenols and antioxidant capacity of seed coat and cotyledon from Brazilian and Peruvian bean cultivars (Phaseolus vulgaris L.). J. Agric. Food Chem. 55(1): 90-98. https://doi.org/10.1021/jf062785j

Rawal V. and Navarro D.K. eds. 2019. The global economy of pulses. FAO, Rome, p. 190.

Revilla I. and Vivar-Quintana A.M., 2008. Effect of canning process on texture of Faba beans (Vicia Faba). Food Chem. 106(1): 310314. https://doi.org/10.1016/j.foodchem.2007.02.046

Ribeiro N.D., Casagrande C.R., Mezzomo H.C., Kläsener G.R. and Steckling S.D.M., 2019. Consumer preference and the technological, cooking and nutritional quality of carioca beans. Ciênc. Agrár. 40(2): 651-669. https://doi. org/10.5433/1679-0359.2019v40n2p651

Ribeiro N.D., Storck, L. and Poersch, N.L., 2008. Classificação de lotes comerciais de feijão por meio da claridade do tegumento dos grãos. Ciência Rural 38(7): 2042-2045. https://doi. org/10.1590/S0103-84782008000700039

Ringuette, C., Finley J., Prinyawiwatkul W. and King J.M., 2018. Development of reduced glycemic load/high fiber ravioli using bean flour. J. Culin. Sci. Technol. 16(4): 336-356. https://doi.org/ 10.1080/15428052.2017.1391147

Rodrigues L.L., Rodrigues L.A., de Souza T.L.P.O., Melo L.C. and Pereira H.S., 2019. Genetic control of seed coat darkening in common bean cultivars from three market classes. Crop Sci. 59(5): 2046-2054. https://doi.org/10.2135/cropsci2019.03.0161

Rupollo G., Vanier N.L., da Rosa Zavareze E., de Oliveira M., Pereira J.M., Paraginski R.T., et al. 2011. Pasting, morphological, thermal and crystallinity properties of starch isolated from beans stored under different atmospheric conditions. Carbohydr. Polym. 86(3): 1403-1409. https://doi.org/10.1016/j. carbpol.2011.06.055

Scariot M.A., Tiburski G., Reichert Jr. F.W., Radünz L.L. and Meneguzzo M.R.R., 2017. Moisture content at harvest and drying temperature on bean seed quality. Pesqui. Agropecu. Trop. 47: 93-101. https://doi.org/10.1590/1983-40632016v4743135

Schmutz J., McClean P.E., Mamidi S., Wu G.A., Cannon S.B., Grimwood J., et al. 2014. A reference genome for common bean and genome-wide analysis of dual domestications. Nat. Genet. 46(7): 707-713. https://doi.org/10.1038/ng.3008
Schoeninger V., Coelho S.R.M., Bassinello P.Z., Prado N.V.d., Soares T.Z.B. and Siqueira V.C., 2020. Adaptability of brazilian beans cultivars to industrial canning. Ciênc. Rural 50(9). https:// doi.org/10.1590/0103-8478cr20200048

Shiga T.M. 2004. Changes in the cell wall polysaccharides during storage and hardening of beans. Food Chem. 84(1): 53-64. https://doi.org/10.1016/s0308-8146(03)00166-3

Silva F., Melo P., Pereira H. and Melo L., 2014. Genetic control and estimation of genetic parameters for seed-coat darkening of carioca beans. Genet. Mol. Res. 13: 6486-6496. https://doi. org/10.4238/2014.August.25.12

Silva F., Pereira H., Melo P. and Melo L., 2018. Selection of parents and segregating populations of common bean with high agronomic potential and slow seed-coat darkening. Pesqui. Agropecu. Trop. 48: 75-82. https://doi.org/10.1590/1983-40632018v4849519

Silva G.S.D., Ramalho M.A.P., Abreu A.D. and Silva F.B., 2008. Genetic control of early grain darkening of carioca common bean. Crop. Breed. Appl. Biotechnol. 8: 299-304. https://doi. org/10.12702/1984-7033.V08N04.A07

Singh N. 2017. Pulses: an overview. J. Food Sci. Technol. 54(4): 853857. https://doi.org/10.1007/s13197-017-2537-4

Singh N., Kaur M., Sandhu K.S. and Sodhi N.S., 2004. Physicochemical, cooking and textural characteristics of some Indian black gram (Phaseolus mungo L) varieties. J. Sci. Food Agric. 84(9): 977-982. https://doi.org/10.1002/jsfa.1744.

Siqueira B.S., Bassinello P.Z., Malgaresi G., Pereira W.J. and Fernandes K.F., 2016a. Analyses of technological and biochemical parameters related to the HTC phenomenon in carioca bean genotypes by the use of PCA. LWT. 65: 939-945. https://doi. org/10.1016/j.lwt.2015.09.030

Siqueira B.S., Bassinello P.Z., Santos S.C., Malgaresi G., Ferri P.H., Rodriguez A.G., et al. 2016b. Do enzymatic or nonenzymatic pathways drive the postharvest darkening phenomenon in carioca bean tegument? LWT. 69: 593-600. https://doi. org/10.1016/j.lwt.2016.01.079

Siqueira B.S., Fernandes K.F., Brito P.V.A. and Santos F.C.A., 2018. Histochemical and ultrastructural characterization of easy-tocook and hard-to-cook carioca bean genotypes. LWT. 97: 117123. https://doi.org/10.1016/j.lwt.2018.06.048

Siqueira B., Pereira W., Batista K., Oomah B.D., Fernandes K. and Bassinello P., 2014. Influence of storage on darkening and hardening of slow- and regular-darkening carioca bean (Phaseolus vulgaris L.) genotypes. J. Agric. Stud. 2: 87-104. https://doi. org/10.5296/jas.v2i2.5859

Siqueira B., Vianello R.P., Fernandes K.F. and Bassinello P.Z., 2013. Hardness of carioca beans (Phaseolus vulgaris L.) as affected by cooking methods. LWT. 54(1): 13-17. https://doi.org/10.1016/j. lwt.2013.05.019

Souza T., Pereira H., Aguiar M., Costa J., Faria L., Abreu A., et al., 2020. Embrapa common bean breeding program: main objectives and opportunities for collaborations, Annual Report of the Bean Improvement Cooperative, 13-14. Available from: http:// www.bic.uprm.edu/.

Spitti A.M.D.S., Carbonell S.A.M., Dias C.T.d.S., Sabino L.G., Carvalho C.R.L. and Chiorato A.F., 2019. Carioca bean genotypes for tolerance to grain darkening by natural and 
accelerated methods. Ciênc. Agrotecnologia 43. https://doi. org/10.1590/1413-7054201943012519

Tyler R., Wang N. and Han J., 2017. Composition, nutritional value, functionality, processing, and novel food uses of pulses and pulse ingredients. Cereal Chem. 94(1): 1-1. https://doi.org/10.1094/ CCHEM-12-16-0500-R

US-DHHS. 2015. 2015-2020 Dietary guidelines for Americans, U.S. Department of Health and Human Services and U.S. Department of Agriculture. 8th ed. USDA. Available from: https://health. gov/our-work/food-nutrition/previous-dietary-guidelines/2015.

Wani I.A., Sogi D.S. and Gill B.S., 2013. Physical and cooking characteristics of black gram (Phaseolus mungoo L.) cultivars grown in India. Int. J. Food Sci. Technol. 48(12): 2557-2563. https:// doi.org/10.1111/ijfs.1224.9
Wani I.A., Sogi D.S., Wani A.A. and Gill B.S., 2017. Physical and cooking characteristics of some Indian kidney bean (Phaseolus vulgaris L.) cultivars. J. Saudi Soc. Agric. Sci. 16(1): 7-15. https://doi.org/10.1016/j.jssas.2014.12.002

Yadav U., Singh N., Kaur A. and Thakur S., 2018. Physico-chemical, hydration, cooking, textural and pasting properties of different adzuki bean (Vigna angularis) accessions. J. Food Sci. Technol. 55(2): 802-810. https://doi.org/10.1007/s13197-017-2994-9

Yang Q. Q., Gan R.-Y., Ge Y.-Y., Zhang D. and Corke H., 2018. Polyphenols in common beans (Phaseolus vulgaris L.): chemistry, analysis, and factors affecting composition. Compr. Rev. Food Sci. Food Saf. 17(6): 1518-1539. https://doi. org/10.1111/1541-4337.12391 